American Journal of Environmental Sciences 4 (6): 576-582, 2008

ISSN 1553-345X

(C) 2008 Science Publications

\title{
Accumulation and Movement of Four Potentially Toxic Elements in Soils Throughout Five Years, During and After Biosolid Application
}

\author{
Marta Susana Zubillaga and Raúl Silvio Lavado \\ Facultad de Agronomía, Universidad de Buenos Aires, \\ Av. San Martín 4453, 1417, Buenos Aires, Argentina
}

\begin{abstract}
In this research, we have studied the accumulation of four PTEs (Cadmium, copper, lead and zinc) during and after biosolid application, in two soils with different clay content and their eventual movement with depth. The study was performed in the Province of Buenos Aires, Argentina, on a Typic Argiudoll and on a Typic Hapludoll. Treatments were: control and biosolid application, at doses of $14 \mathrm{Mg} \mathrm{ha}^{-1} \mathrm{year}^{-1}$ (dry matter). There were two types of sampling: (i) Topsoil sampling, at 0$0.15 \mathrm{~m}$ depth, taken throughout five years and (ii) Depth soil sampling at regular intervals of $0.33 \mathrm{~m}$ from top soil to 3-4 m depth, taken two years after biosolid application. All samples were taken on April. PTEs, extracted hydrochloric, sulfuric and nitric acids (total) or extracted with DiethyleneTriaminePentaacetic acid-DTPA (available), were determined by ICP. Total concentrations of PTEs in topsoils of both soils did not increase significantly due to biosolid application. The exception was the significantly high Pb concentration in the Typic Hapludoll. DTPA extractable metals showed some concentration changes throughout the studied period. Total and available PTEs did not show mobility with the depth of both soils. The exception was total $\mathrm{Cd}$ in the Typic Argiudoll, which moved in depth. With only those two exceptions, there is neither PTEs accumulation in topsoils nor PTEs movements in soil depth. The first could be attributed to biosolid composition and dosage used in the region. The lack of movement in depth appears more related to the characteristics of the studied soils.
\end{abstract}

Key words: Biosolids, PTEs accumulation, PTEs movement, mollisols

\section{INTRODUCTION}

The concentration of Potentially Toxic Elements (PTEs) in noncontaminated soils is related to parent material, soil forming processes, degree of mineral alteration $^{[1,2]}$ and soil clay content ${ }^{[3]}$. Different anthropogenic processes incorporate PTEs in soils at different rates. Biosolids, used due to their beneficial effects on agriculture ${ }^{[4]}$, usually incorporate PTEs to soils ${ }^{[5,6]}$. Evidence indicates that PTEs from biosolids accumulated in soils can be absorbed by plants, resulting in increases of PTE concentration in plant tissues $^{[7]}$. This absorption could lead to an undesirable metal accumulation in the food chain ${ }^{[8]}$. Therefore, regulations in most countries attempt to minimize soil accumulation danger from the application of biosolids (e.g., EPA 503).

Normally PTEs enter and accumulate in topsoils; therefore, knowing their fate in the soil body is another topic of interest. There are two main ideas about PTEs' fate in soils. Some results prove that PTEs are mobile and a substantial redistribution of those elements occurs within the subsoil and aquifers ${ }^{[8,9]}$. This mobility of PTEs is attributed to their complexation by dissolved organic compounds, released from the soil organic matter or the biosolids themselves ${ }^{[10,11]}$. Conversely, other authors indicate that there is PTEs stabilization and lack of movement and even their availability decreases. This fate was attributed to a progressive change to less soluble forms, due to occlusion in $\mathrm{Fe}$ and $\mathrm{Al}$ oxides, or precipitation as silicates, phosphates, or carbonates $^{[12,13]}$ or sequestration on organic compounds $^{[14]}$.

The extraction with strong acids does not indicate some of those PTEs changes in soils and it is not a good indicator of their absorption by roots ${ }^{[15,16]}$. Weak extractants (e.g., DiethyleneTriaminePentaacetic acid, DTPA; EthyleneDiamineTetraacetic, EDTA or $\mathrm{CaCl}_{2}$ ) were proposed to represent PTE bioavailability. Nevertheless, there are reports showing strong

Corresponding Author: Marta Zubillaga, Cátedra de Fertilidad y Fertilizantes, Facultad de Agronomía, Universidad de Buenos Aires, Av. San Martín 4453, 1417, Ciudad de Buenos Aires, Argentina Tel: +54-11-4524-8000 (8228) 
correlation between weak extractant-metals and plant absorbed-metals ${ }^{[17,18]}$ and other showing not relation at all $^{[16]}$. The DTPA extraction however is very common and, in some cases, was used to study the metal mobility in soils ${ }^{[19]}$.

The DTPA determination could be useful to evaluate metal availability in short term. However, according to Juste and Mench ${ }^{[20]}$, it is better to express metal bioavailability in relation to its total content, due to eventual spatial and temporal changes. On the other hand, the eventual PTEs redistribution through the soil profile can be indirectly observed, by quantifying its concentration in different soil depths ${ }^{[21,22]}$. Our objectives were to study the possible accumulation of four PTEs (cadmium $(\mathrm{Cd})$, copper $(\mathrm{Cu})$, lead $(\mathrm{Pb})$ and zinc $(\mathrm{Zn})$ during and after biosolid application, in two soils with different clay content and their eventual movement with depth.

\section{MATERIALS AND METHODS}

The study was performed in two trials carried out from 1999 to 2003 in the Province of Buenos Aires, Argentina. They were located in the town of Solís (34 $4^{\circ} 17^{\prime} 44.8^{\prime}$ ' S; 59 $19^{\circ} 12.1^{\prime}, \mathrm{W}$ ) on a Typic Argiudoll and, $146 \mathrm{~km}$ apart, in the city of 25 de Mayo (35'22‘38.9”S; $60^{\circ} 03$ '48.5”W) on a Typic Hapludoll soil. Both soils have the same origin (loess-like sediments) and illite as the predominant clay. They differ in organic matter and clay contents and related properties as CEC. In both locations the landscape is flat and run-off is not noticeable. Experiments were performed at farmer level, using field machinery. Both trials were designed at random with two treatments and three replications. Each replication was $2000 \mathrm{~m}^{2}$ size. The treatments were: (i) control, without biosolid application and (ii) biosolid application, at doses of $14 \mathrm{Mg} \mathrm{h}^{-1}$ year $^{-1}$ (dry matter), applied three consecutive years. The crops were wheat (1999), maize (2000) and sunflower (2001). After biosolid was no longer applied, crops were discontinued and a pasture was seeded in both locations. The chemical composition of the biosolid used in the study is shown in Table 1.

There were two soil samplings: (i) Topsoil sampling: a composite soil sample, from 15 subsamples taken at random at $0.00-0.15 \mathrm{~m}$ depth from each plot.

Table 1: Chemical composition of the biosolid used

\begin{tabular}{lc}
\hline PTEs & Content in biosolid, $\left(\mathrm{mg} \mathrm{kg}^{-1}\right)$ \\
\hline Cadmium & 3.5 \\
Cooper & 540.0 \\
Lead & 440.0 \\
Zinc & 2500.0 \\
\hline
\end{tabular}

month of the summer crop harvest in the Southern Hemisphere. No plant samples were taken. (ii) Depth soil sampling: Three replicates per plot were taken from top soil to $3 \mathrm{~m}$ depth in the Typic Hapludoll and $4 \mathrm{~m}$ depth in the Typic Argiudoll, at regular intervals of $0.33 \mathrm{~m}$. It was used an Eijelkamp soil sampler with a percussion hammer. Samples were taken on April 2002 and 2003. Soil samples were dried at room temperature, ground and passed through a stainless steel 10-mesh sieve $(2 \mathrm{~mm})$. Two form of $\mathrm{Cd}, \mathrm{Cu}, \mathrm{Pb}$ and $\mathrm{Zn}$ were determined: (i) PTEs extracted by digestion with hydrochloric, sulfuric and nitric acids ${ }^{[23]}$ and PTEs extracted with DTPA $^{[24]}$. PTEs in all extracts were determined using Inductively Coupled Argon Plasma Emission Spectrometry (ICPES). Obtained values are considered from now on the Total and the Available forms, respectively. Determinations were contrasted with NIST standard reference material. Soils were characterized following standard analytical procedures $^{[24]}$. All data were statistically tested for analysis of variance (ANOVA) with the Statistix analytical program. The Least Significant Difference (LSD) test was then employed to determine which values were significantly different from one another $(\mathrm{p}<0.05)$.

\section{RESULTS AND DISCUSSION}

Characteristics of biosolid and soils: The chemical composition of the biosolid Table 1 was within the permissible values to use in agriculture, according to Argentinean regulations ${ }^{[25]}$. The main chemical and physical properties of the two soils appear in Table 2. Soil profile characteristics are normal for those Great Groups of soils in the area ${ }^{[26]}$. The Typic Argiudoll is expected to have a larger metal absorption capacity than the Typic Hapludoll ${ }^{[2]}$, mainly due to the higher soil $\mathrm{OM}, \mathrm{CEC}$ and clay content of the former.

Total and available PTEs accumulation on topsoil (0.00-0.15 m): Soil Total and Available PTEs concentrations showed no significant differences in the control treatments throughout the five studied years. Biosolid application treatment did not show statistically significant differences on Total PTEs concentrations during the three years of biosolid application. However, the Available PTEs showed significant differences with the control. In general, when the biosolid application was completed, concentrations of available PTEs showed statistical differences in comparison with the three previous years. From these results, data were organized as follows: (i) Control (C), average PTEs concentration on soils that did not receive biosolids; (ii) 
Biosolid application (B1), average PTEs concentration on soils during three years of biosolid application; and (iii) After biosolid application (B2), average PTEs concentration on soils in the 2 years following the last biosolid application (Fig. 1).

Total PTEs concentrations on the Typic Argiudoll were 58-118\% higher compared to the Typic Hapludoll. Available $\mathrm{Cu}, \mathrm{Pb}$ and $\mathrm{Zn}$ concentrations were higher in the Typic Argiudoll, while Cd concentration was higher in the Typic Hapludoll. Biosolid application did not cause significant $(p<0.05)$ changes in total PTEs concentrations in both soils in the two studied periods. The exception was the significant $(\mathrm{p}<0.05)$ increase in total $\mathrm{Pb}$ in the Typic Hapludoll, after the biosolid application ended (B2). The high variability of the results produced that in the most of the cases significant differences between them were not observed either. Anyway, in both soils, the available concentrations of $\mathrm{Pb}$ and $\mathrm{Zn}$ were significantly higher $(\mathrm{p}<0.05)$ when biosolids were applied (B1) compared with the Control (C) and after the biosolid application (B2). DTPA extractable- $\mathrm{Cu}$ showed a similar tendency. Other authors have found similar results and they attribute them to the progressive immobilization of PTE toward
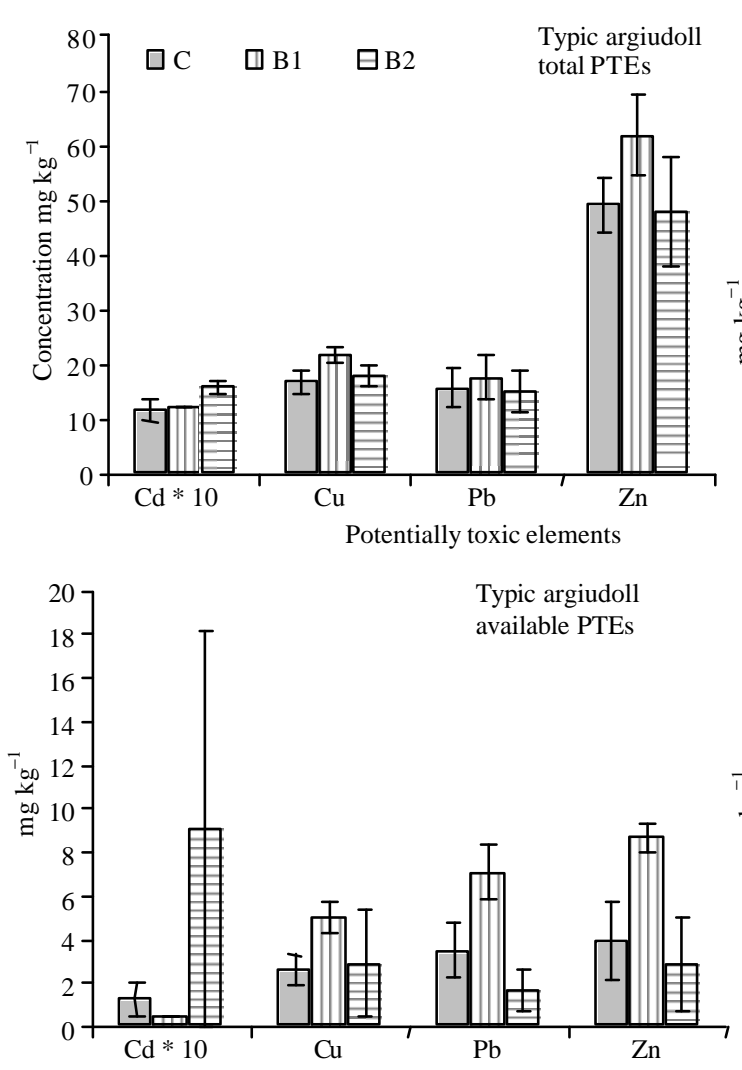

less soluble forms ${ }^{[22,28]}$. The concentration of available $\mathrm{Cd}$ during biosolid application period on the Typic Argiudoll, showed a tendency to decrease $(p<15.00)$. This fact could be attributable to the sewage sludge matrix is a major adsorptive medium for PTEs in sludge-treated soils ${ }^{[29]}$.

Table 2: Physical and chemical characteristics of both soils before receiving biosolids

\begin{tabular}{|c|c|c|c|c|c|c|c|}
\hline Horizon & $\begin{array}{l}\text { Depth } \\
\mathrm{cm}\end{array}$ & Clay & $\begin{array}{l}\text { Silt } \\
\end{array}$ & Sand & OM & $\begin{array}{l}\text { CEC } \\
\left(\mathrm{Cmol}^{-1}\right. \\
\left.\mathrm{kg}^{-1}\right) \\
\end{array}$ & $\begin{array}{c}\mathrm{pH} \\
(1: 2.5 ; \\
\left.\mathrm{H}_{2} \mathrm{O}\right)\end{array}$ \\
\hline \multicolumn{8}{|c|}{ Typic argiudoll } \\
\hline Ap & $0-12$ & 29.8 & 58.4 & 11.8 & 3.66 & 18.0 & 5.5 \\
\hline Ad & $12-22$ & 30.6 & 57.5 & 11.9 & 3.14 & 15.8 & 5.7 \\
\hline BA & $22-40$ & 40.2 & 49.9 & 9.9 & 1.74 & 18.2 & 5.9 \\
\hline Bt1 & $40-73$ & 62.6 & 29.5 & 7.9 & 1.08 & 36.6 & 5.9 \\
\hline Bt2 & $73-122$ & 50.5 & 40.0 & 9.5 & 0.86 & 23.5 & 6.5 \\
\hline $\mathrm{BC}$ & $122-160$ & 42.6 & 47.8 & 9.6 & 0.30 & 26.8 & 6.8 \\
\hline \multicolumn{8}{|c|}{ Typic hapludoll } \\
\hline Ap & $0-12$ & 11.4 & 14.3 & 74.3 & 2.22 & 7.6 & 5.9 \\
\hline A & $12-24$ & 8.3 & 15.0 & 76.7 & 1.92 & 7.8 & 5.6 \\
\hline $2 \mathrm{Ab}$ & $24-48$ & 11.3 & 13.3 & 75.4 & 1.48 & 7.5 & 5.8 \\
\hline $2 \mathrm{ACb}$ & $48-72$ & 10.4 & 12.1 & 77.5 & 0.74 & 6.2 & 6.3 \\
\hline $2 \mathrm{C}$ & $72-102$ & 7.8 & 8.6 & 83.6 & 0.28 & 5.3 & 6.4 \\
\hline $3 \mathrm{Cx}$ & $102-124$ & 14.5 & 9.0 & 76.5 & 0.42 & 6.5 & 6.4 \\
\hline $4 \mathrm{C}$ & $124-166$ & 11.4 & 7.8 & 80.8 & 0.24 & 6.5 & 6.7 \\
\hline
\end{tabular}
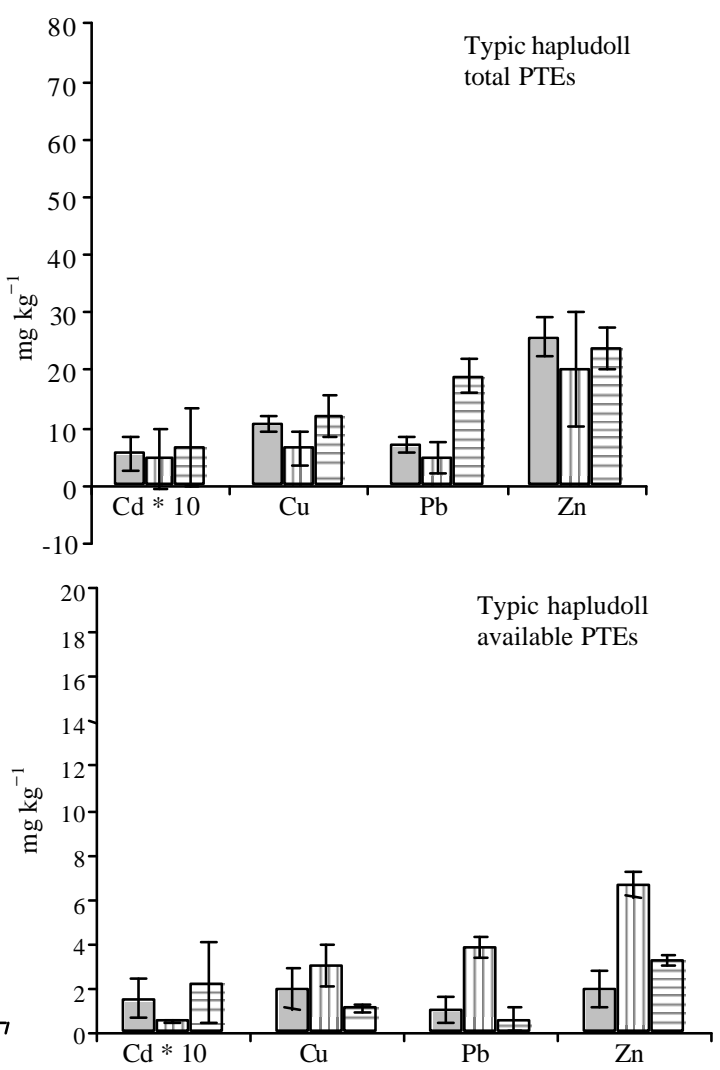

Fig. 1: Average content of available and total PTE in top soils sampled of different situations related to biosolid application. Cadmium concentrations are multiplied times 10. Bars indicate the Standard error 
Table 3 shows the proportion of available PTEs in relation to the total PTEs content in both soils. There are two patterns: For $\mathrm{Cu}, \mathrm{Pb}$ and $\mathrm{Zn}$ the proportion of available form increased during biosolid application but decreased after the biosolid application. For $\mathrm{Cd}$ the reverse is true. Those relative changes in metal availability coincide with changes in DTPA metal concentration (Fig. 1), Stacey et al. ${ }^{[30]}$, emphasized that PTEs chemical forms can be changed by organic matter mineralization when biosolids are applied to soils. The changes in $\mathrm{Cu}, \mathrm{Pb}$ and $\mathrm{Zn}$ Availability could be attributed to metal complexation with soluble carbon compounds from biosolids ${ }^{[31]}$. Conversely, according to Torri and Lavado ${ }^{[32]}$, Cd behavior would be associated with its occurrence in less soluble forms.
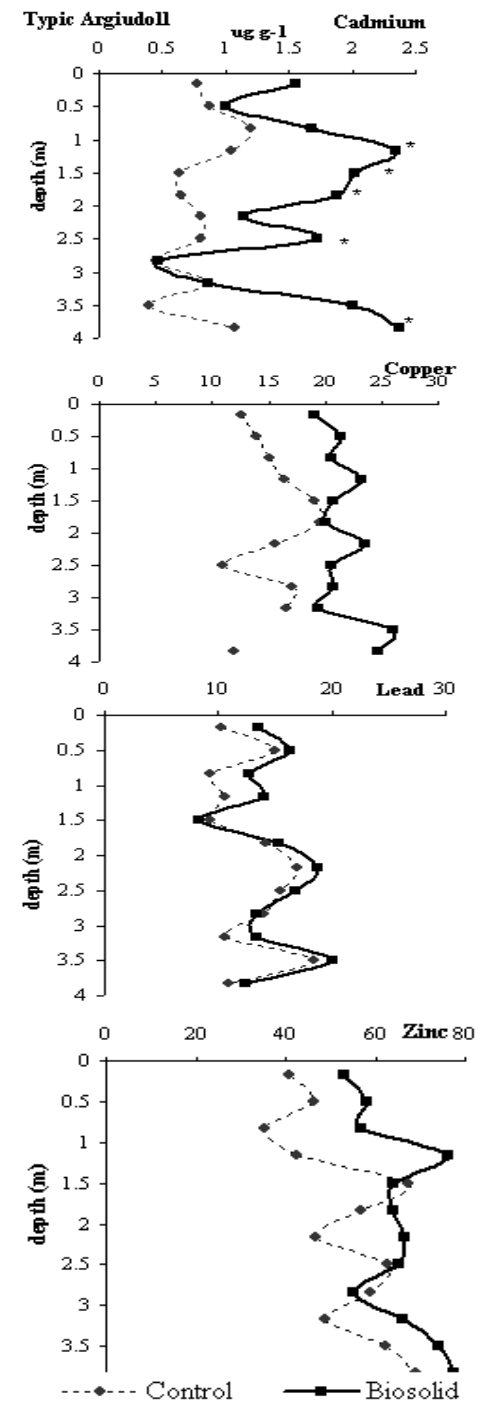

Variation in concentration of PTEs with soil depth after biosolid application: There were no statistical differences between sampling dates. Figure 2 and 3

Table 3: Proportion of Available PTE related to total PTE in percentage terms

\begin{tabular}{lcccc}
\hline Treatments & $\mathrm{Cd}(\%)$ & $\mathrm{Cu}(\%)$ & $\mathrm{Pb}(\%)$ & $\mathrm{Zn}(\%)$ \\
\hline Typic argiudoll & & & & \\
Control & 10.7 & 15.2 & 22.1 & 7.9 \\
$\mathrm{~B} 1$ & 4.0 & 22.9 & 39.7 & 14.1 \\
$\mathrm{~B} 2$ & 56.7 & 16.0 & 11.0 & 6.0 \\
Typic hapludoll & & & & \\
Control & 26.7 & 18.2 & 14.4 & 7.6 \\
B1 & 6.9 & 30.2 & 52.7 & 22.0 \\
B2 & 32.8 & 9.1 & 3.0 & 13.7 \\
\hline
\end{tabular}
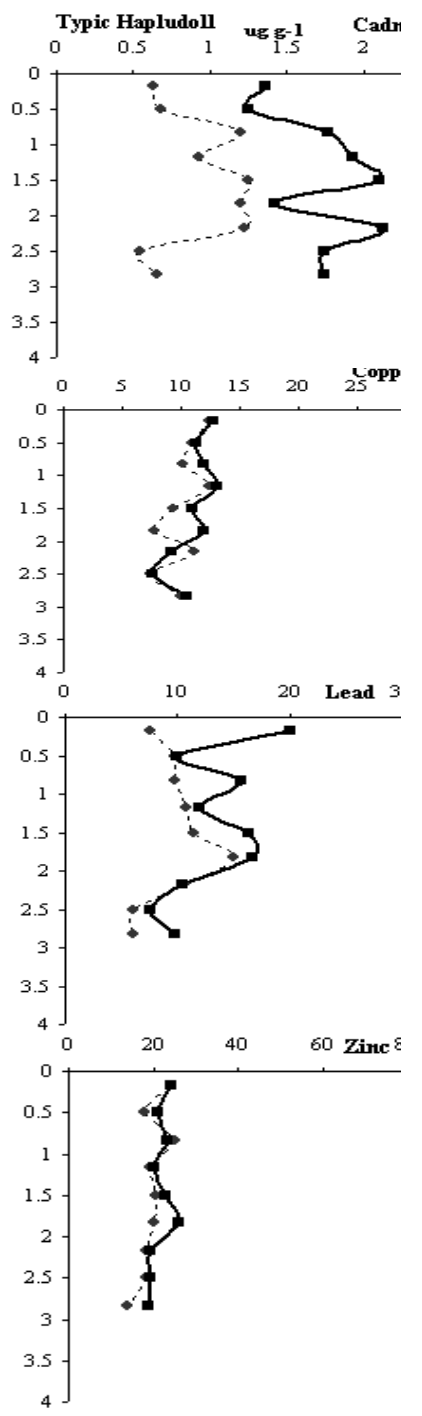

Fig. 2: Total concentration of $\mathrm{Cd}, \mathrm{Cu}, \mathrm{Pb}$ and $\mathrm{Zn}$ on soil depth after biosolid application. * shows statistical differences between treatments $(\mathrm{p}<0.05)$ 
Am. J. Environ. Sci., 4 (6): 576-582, 2008
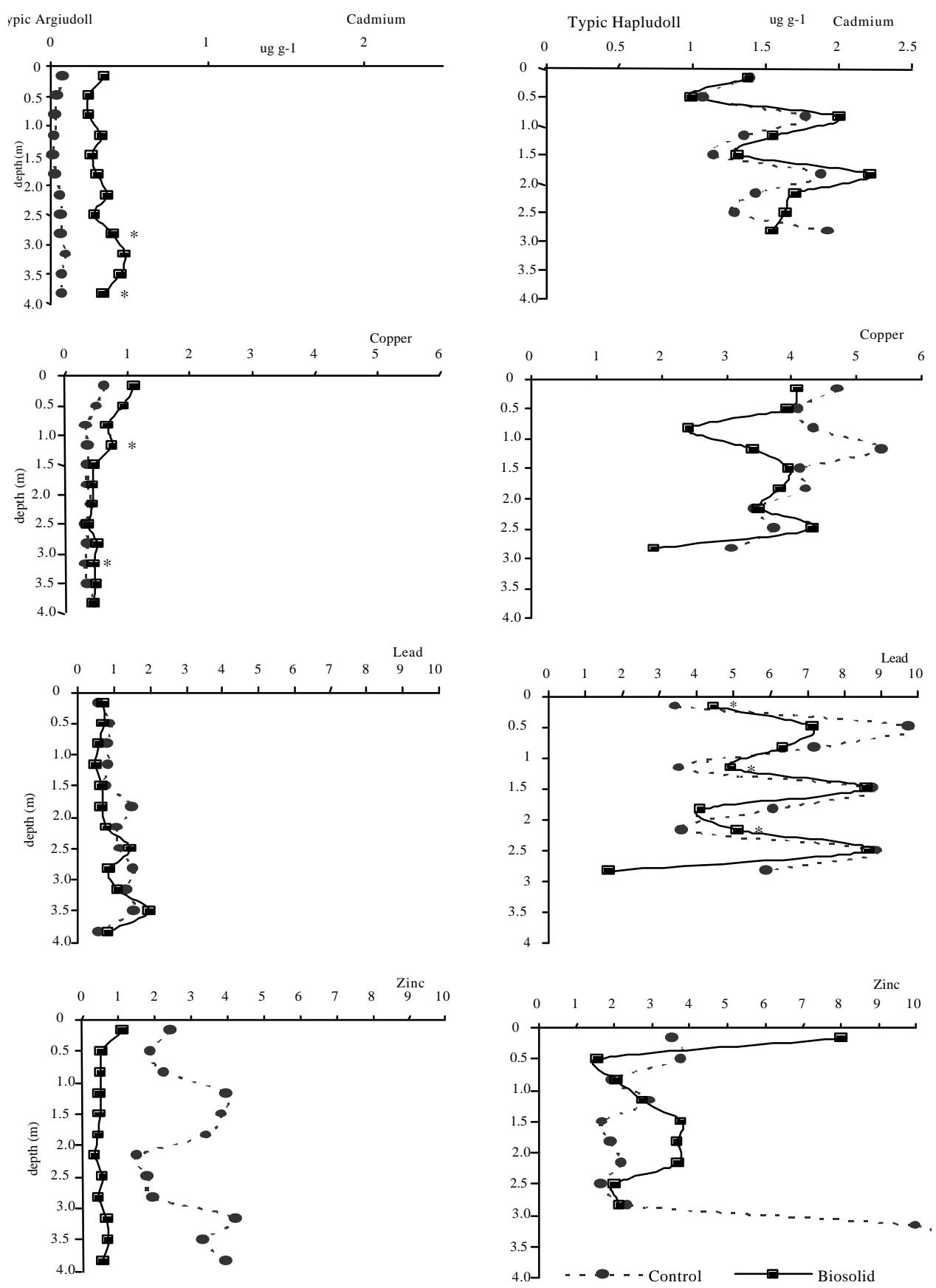

Fig. 3: Available concentration of $\mathrm{Cd}, \mathrm{Cu}, \mathrm{Pb}$ and $\mathrm{Zn}$ on soil depth after biosolid application. * shows statistical differences between treatments $(p<0.05)$

show the average results of both Total and Available PTEs in both soils. Total metal concentrations were in general higher in the Typic Argiudoll as compared with the Typic Hapludoll, but for available PTEs the reverse was true. This is expected to happen as a larger proportion of metals would be adsorbed/precipitated with organic complexes and/or mineral colloids in the Typical Argiudoll due to higher organic and inorganic colloids content (Table 2).

Figure 2 shows the distribution of Total PTEs concentration in depth. Concentrations of metals in total form in superficial soil layers in both soils controls are 
comparable with those of noncontaminated soils of the region $^{[33]}$. However, metal concentrations showed large variations with depth, which were not clearly associated with clay content variations in depth, which is different to previously found results in the area by ${ }^{[33]}$. After biosolid application, an increase in $\mathrm{Cd}$ concentration was observed in some deep layers of the Typic Argiudoll. The other PTEs in this soil and all of them in the Typic Hapludoll did not show significant differences $(p<0.05)$, although some tendencies to increase the concentrations can be observed.

Figure 3 shows Available PTEs distribution in both soils. Cadmium concentration was higher at the end of the biosolid application in all depths in the Typic Argiudoll although they were significantly different $(\mathrm{p}<0.05)$ from $2 \mathrm{~m}$ depth. The other 3 available PTEs of this soil and all of them in the Typic Hapludoll did not show significant differences $(\mathrm{p}<0.05)$.

\section{CONCLUSION}

Total concentrations of PTEs in topsoils showing different clay and CEC content did not increase significantly due to biosolid application. The exception, for no apparent reason, was the significantly high $\mathrm{Pb}$ concentration in the Typic Hapludoll. DTPA extractable metals showed some concentration changes throughout the studied period. Total and Available PTEs did not show mobility with the depth of both soils. The exception was total $\mathrm{Cd}$ in the Typic Argiudoll, which concentration increased in depth in the biosolid treatment. With only those two exceptions, there is no PTEs accumulation in topsoils and there are no PTEs movements in soil depth. The first could be attributed to biosolid composition and dosage used in the region. The lack of movement in depth appears more related to the characteristics of the studied soils.

\section{REFERENCES}

1. Bolan, N.S. and V.P. Duraisamy, 2003. Role of inorganic and organic soil amendments on immobilization and phytoavailability of heavy metals: A review involving specific case studies. Aust. J. Soil Res., 41: 533-555. http://cat.inist.fr/ ?aModele $=$ afficheN\&cpsidt $=14898068$.

2. Frink, C.R., 1996. A perspective on metals in soils. J. Soil Contam., 5: 329-359. http://md1.csa.com/ partners/viewrecord.php?requester $=\mathrm{gs} \&$ collection $=$ ENV\&recid $=4003728 \& \mathrm{q}=\mathrm{A}+$ perspective + on + meta ls + in + soils \&uid $=\&$ setcookie $=$ yes.

3. Smith, S.R., 1996. Agricultural Recycling of Sewage Sludge and the Environment. 1st Edn., CAB Intenational, Wallingford, UK., ISBN: 0851989802.
4. McBride, M.B., B.K. Richards, T. Steenhuis and G. Spiers, 1999. Long-term leaching of trace elements in a heavily sludge-amended silty clay loam soil. Soil Sci., 164: 613-623. http://cat.inist. fr/?aModele $=$ afficheN\&cpsidt $=1946041$.

5. Keller, C., S.P. McGrath and S.J. Dunham, 2002. Heavy metals in the environment-Trace metal leaching through a soil-grassland system after sewage sludge application. J. Environ. Qual., 31: 1550-1560. http://jeq.scijournals.org/cgi/ content/abstract/31/5/1550.

6. Rate, A.W., K.M. Lee and P.A. French, 2004. Application of biosolids in mineral sands mine rehabilitation: Use of stockpiled topsoil decreases trace element uptake by plants. Bioresour. Technol., 91: 223-231. http://cat.inist.fr/ ?aModele $=$ afficheN\&cpsidt $=15481028$.

7. Chaney, R.L., 1973. Crop and food chain effects of toxic elements in sludges and effluents. Proceedings of the Joint Conference on Recycling Municipal Sludges and Effluents on Land, July 913, Champaign, IL., Washington, DC., USA., pp: 129-141.

8. McBride, M.B., 1995. Toxic metal accumulation from agricultural use of sludge: Are USEPA regulations protective? J. Environ. Qual., 24: 518. http://jeq.scijournals.org/cgi/content/abstract/24/1/5.

9. Holm, P.E., T.H. Christensen, S.E. Lorenz, R.E. Hamon, H.C. Domingues, E.M. Sequeira and S.P. McGrath, 1998. Measured soil water concentration of cadmium and zinc in plant pots and estimated leaching outflows from contaminated soils. Water Air Soil Pollut., 102: 105-115.DOI: 10.1023/A:1004964200904.

10. Richards, B.K., T.S. Steenhuis, J.H. Peverly and M.B. McBride, 2000. Effect of sludge-processing mode, soil texture and $\mathrm{pH}$ on metal mobility in undisturbed soil columns under accelerated loading. Environ. Pollut., 109: 327-346. DOI: 10.1016/S0269-7491(99)00249-3.

11. Al-Wabel, M.A., D.M. Heil, D.G. Westfall and K.A. Barbarick, 2002. Solution chemistry influence on metal mobility in biosolids-amended soils. J. Environ. Qual., 31: 1157-1165. http://jeq. scijournals.org/cgi/content/abstract/31/4/1157

12. Smith, S.R., 1997. Long-term Effects of Zinc, Copper and Nickel in Sewage Sludge-Treated Agricultural Soil. Proceeding of the 4th International Conference on the Biogeochemistry of Trace Elements, June 23-26, Berkeley, CA., CRREL, Hanover, NH., pp: 691-692. 
13. Brown, S.L., R.L. Chaney, J.S. Angle and J.A. Ryan, 1998. The phytoavailability of cadmium to lettuce in longterm biosolids-amended soils. J. Environ. Qual., 27: 1071-1078. http://jeq. scijournals.org/cgi/content/abstract/27/5/1071.

14. González-Chávez, M.C., R. Carrillo-González, S.F. Wrightb and K.A. Nichols, 2004. The role of glomalin, a protein produced by arbuscular mycorrhizal fungi, in sequestering potentially toxic elements. Environ. Pollut., 130: 317-323. http://cat. inist.fr/?aModele $=$ afficheN\&cpsidt $=15839106$

15. Srikanth, R. and S.R.P. Reddy, 1991. Lead, cadmium and chromium levels in vegetables grown in urban sewage sludge in India. Food Chem., 40: 229-234.

16. Lavado, R.S., M. Rodríguez, R. Alvarez, M.A. Taboada and M.S. Zubillaga, 2007. Transfer of potentially toxic elements from biosolid-treated soils to maize and wheat crops. Agric. Ecosyst. Environ., 118: 312-318. http://cat.inist.fr/ ?aModele $=$ afficheN\&cpsidt $=18409393$

17. Wang, X.P., X.Q. Shan, S.Z. Zhang and B. Wen, 2004. A model for evaluation of the phytoavailability of trace elements to vegetables under the field conditions. Chemosphere, 55: 811-822.

18. Kabata-Pendias, A., 1993. Behavioural properties of trace metals in soils. Applied Geochem., 2: 3-9.

19. Shuman, L.M., F.C. Boswell, K. Ohki, M.B. Parker and D.O. Wilson, 1980. Critical soil manganese deficiency levels for four extractants for soybeans grown in sandy soil. Soil Sci. Soc. Am. J., 44: 1021-1025. http://soil.scijournals.org/ cgi/content/abstract/44/5/1021.

20. Juste, C. and M. Mench, 1992. Long Term Application of Sewage Sludge and its Effects on Metal Uptake by Crops. In: Biogeochemistry of Trace Metals, Adriano, D.C. (Ed.). Lewis Publishers, Boca Raton, pp: 159-193.

21. Baveye, P., M.B. McBride, D. Bouldin, T.D. Hinesly, M.S.A. Dahdoh and M.F. AbdelSabour, 1999. Mass balance and distribution of sludge-borne trace elements in a silt loam soil following long-term applications of sewage sludge. Sci. Total Environ., 227: 13-28.

22. Keller, C., A. Kayser, A. Keller and R. Schulin, 2000. Heavy Metal Uptake by Agricultural Crops from Sewage-Sludge Treated Soils of the Upper Swiss Rhine Valley and the Effect of Time. In: Environmental Restoration of Metals Contaminated Soils, Iskandar, I.K. (Ed.). CRC Press, Boca Raton, FL, pp: 273-291.
23. McGrath, S.P. and C.H. Cunliffe, 1985. A simplified method for the extraction of the metals $\mathrm{Fe}, \mathrm{Zn}, \mathrm{Cu}, \mathrm{Ni}, \mathrm{Cd}, \mathrm{Pb}, \mathrm{Cr}, \mathrm{Co}$ and $\mathrm{Mn}$ from soils and sewage sludges. J. Sci. Food Agric., 36: 794-798.

24. Sparks, D.L., A.L. Page, P.A. Helmke, R.A., Loeppert, P.N. Soltanpour, M.A. Tabatabai, C.T. Jhonston and M.E. Sumner. 1996. Methods of Soil Analysis, Part 3, Chemical Mehods. 3rd Edn., ASA., Madison, Wisconsin, USA., pp: 1390.

25. SADS., 2001. Secretaría de Ambiente y Desarrollo Sustentable. Ministerio de Salud y Ambiente. Resolución 97/01, Anexo 1.

26. Soriano A., R.J.C. León O.E. Sala, R.S. Lavado, V.A. Deregibus, M.A. Cauhépé, O.A. Scaglia, C.A. Velázquez and J.H. Lemcoff, 1991. Río de la Plata Grasslands. In: Ecosystems of the World 8A. Natural Grasslands, Introduction and Western Hemisphere, Coupland, R.T. (Ed.). Elsevier, USA., pp: 367-407.

27. McBride, M.B., B.K. Richards and T. Steenhuis, 2004. Bioavailability and crop uptake of trace elements in soil columns amended with sewage sludge products. Plant Soil, 262: 71-84.

28. Barbarick, K.A. and J.A. Ippolito, 2003. Termination of sewage biosolids application affects wheat yield and other agronomic characteristics. Agron. J., 95: 1288-1294.

29. Hooda, P.S. and B.J. Alloway, 1993. Effects of time and temperature on the bioavailability of $\mathrm{Cd}$ and $\mathrm{Pb}$ from sludge-amended soils. J. Soil Sci., 44: 97-110.

30. Stacey, S., G. Merrington and M.J. MacLaughlin, 2001. The effect of.aging biosolids on the availability of cadmium and zinc in soil. Eur. J. Soil Sci., 52: 313-321.

31. McBride, M.B., B.K. Richards, T. Steenhuis, J.J. Tusso and S. Sauwé, 1997. Mobility and solubility of toxic metals and nutrients in soil fifteen years after sludge application. Soil Sci., 162: 487-500.

32. Torri, S. and R. Lavado, 2002. Distribución y disponibilidad de elementos potencialmente tóxicos en suelos representativos de la provincia de Buenos Aires enmendados con biosólidos. Ciencia del Suelo. 20: 98-109.

33. Lavado, R.S., M.S. Zubillaga, R. Alvarez and M.A. Taboada, 2004. Baseline levels of potentially toxic elements in Pampas Soils. Soil Sediment Contam., 13: 1-11. 